\title{
PENERAPAN RECIPROCAL TEACHING DENGAN KARTU PERAN UNTUK MENINGKATKAN KEMAMPUAN PENALARAN MATEMATIS MATERI TRIGONOMETRI
}

\author{
Elisa Dewi Puspitasari \\ SMA Negeri 8 Malang \\ lisadepita@gmail.com
}

\begin{abstract}
Abstrak
Tujuan penelitian ini adalah untuk mendeskripsikan penerapan Reciprocal Teaching dengan kartu peran untuk meningkatkan kemampuan penalaran matematis siswa pada materi trigonometri. Penalaran matematis merupakan berpikir mengenai permasalahanpermasalahan matematika secara logis untuk menyelesaikan suatu permasalahan dan memberikan alasan terhadap suatu penyelesaian. Salah satu pembelajaran untuk mengatasi rendahnya kemampuan penalaran matematis adalah pembelajaran model Reciprocal Teaching dengan menggunakan karrtu peran. Langkah-langkah kegiatan Reciprocal Teaching meliputi question generating, clarifying, predicting, dan summarizing. Sebelum dilakukan langkah kegiatan Reciprocal Teaching, siswa diberikan kartu peran untuk menentukan siswa yang menjadi guru model. Penelitian ini merupakan penelitian tindakan kelas. Berdasarkan penelitian yang telah dilakukan diketahui bahwa penerapan model Reciprocal Teaching meningkatkan kemampuan penalaran matematis siswa kelas XI IPA 2 SMA Negeri 8 Malang pada materi Trigonometri dengan meningkatnya rata-rata kelas dari nilai awal 37 menjadi 60 pada siklus I dan menjadi 73 pada siklus II. Selain itu rata-rata persentase peningkatan penalaran matematis siswa juga meningkat dari $60 \%$ menjadi $73 \%$.
\end{abstract}

Kata kunci: reciprocal teaching, kartu peran, penalaran matematis

\begin{abstract}
The purpose of this study is to describe the application of Reciprocal Teaching with role cards to improve student mathematical reasoning abilities on trigonometry material. Mathematical reasoning is thinking about mathematical problems logically to solve a problem and give reasons for a solution. One of the lessons learned to overcome the low mathematical reasoning ability is the learning of Reciprocal Teaching models using role cards. The steps of Reciprocal Teaching activities include question generating, clarifying, predicting, and summarizing. Before the Reciprocal Teaching steps are carried out, students are given a role card to determine the students who become model teachers. This research is a classroom action research. Based on the research that has been done, it is known that the application of the Reciprocal Teaching model increases the mathematical reasoning ability of students in XI grade IPA 2 of SMA Negeri 8 Malang on the Trigonometry with an increase
\end{abstract}




\section{Elisa Dewi Puspitasari}

Penerapan Reciprocal Teaching dengan Kartu Peran untuk Meningkatkan Kemampuan Penalaran Matematis Materi Trigonometri

in class average from initial 73 to 60 in cycle I and to 73 in cycle II. In addition, the average percentage increase in students' mathematical reasoning also increased from $60 \%$ to $73 \%$.

Keywords: reciprocal teaching, role card, mathematical reasoning

\section{PENDAHULUAN}

Kemajuan suatu negara dapat diukur dari kualitas layanan pendidikan. Sekolah merupakan suatu lembaga yang memberikan layanan pendidikan formal bagi siswa. Sekolah juga berfungsi memenuhi dan memuaskan kebutuhan-kebutuhan siswa dalam hal pendidikan (Hamalik, 2003). Sekolah yang mampu memberikan layanan pendidikan berkualitas baik diharapkan mampu mencetak lulusan yang berkualitas baik pula. Guru merupakan ujung tombak pemberi layanan pendidikan. Guru yang mampu menyajikan pembelajaran yang baik diharapkan dapat melahirkan siswa yang berkualitas baik.

Trigonometri merupakan salah satu materi yang menjadi momok bagi sebagian siswa SMA berdasarkan observasi dan dialog pada saat pembelajaran rumus jumlah dan selisih sudut di kelas XII IPA 2. Siswa terlihat kesulitan dalam menjawab soal-soal berbentuk uraian atau soal pembuktian pada penilaian harian materi rumus jumlah dan selisih sudut yang ditunjukkan dengan nilai rata-rata kelas yang sangat rendah yaitu 31,7. Rendahnya kemampuan penalaran matematis siswa merupakan salah satu penyebab siswa kesulitan dalam menyelesaikan masalah. Hal ini dikarenakan kegiatan menalar seperti mengembangkan ide, mengeksplorasi fenomena, memberikan alasan atas suatu jawaban, dan membuat dugaan matematis sangat penting dalam memahami matematika (Arifendi \& Setiawan, 2019).

Penalaran dapat dibagi menjadi dua jenis, yaitu penalaran deduktif dan induktif. Penalaran deduktif adalah proses penalaran untuk memperoleh kesimpulan khusus berdasarkan pengetahuan prinsip atau pengalaman yang umum sedangkan penalaran induktif adalah proses penalaran untuk memperoleh aturan atau prinsip umum berdasarkan contoh-contoh kasus (Ramdani, 2012). Penalaran matematis adalah berpikir logis untuk menyelesaikan masalah matematika dengan memilah apa yang diperlukan dan tidak diperlukan dalam menyelesaikan masalah dan untuk menjelaskan alasan atas penyelesaian tersebut (Wulandari, 2011).

Kemampuan penalaran menuntut siswa untuk mampu memberikan alasan logis terkait dengan jawaban yang diberikan. Menurut Ridwan (2017) indikator kemampuan penalaran matematis antara lain manipulasi matematis, menarik kesimpulan, memberikan alasan atau bukti terhadap satu atau beberapa solusi dan memeriksa kesahihan suatu argumen. 


\section{Elisa Dewi Puspitasari}

Penerapan Reciprocal Teaching dengan Kartu Peran untuk Meningkatkan Kemampuan Penalaran Matematis Materi Trigonometri

Sedangkan menurut Ramdani (2011) terdiri dari memberikan penjelasan tentang model, gambar, fakta, sifat, hubungan, atau pola yang ada, memberikan argumen logis dan menarik kesimpulan logis. Indikator kemampuan penalaran dalam penelitian ini adalah mengajukan pertanyaan, memberikan alasan terhadap kebenaran solusi, menganalisis pernyataan dan membuat kesimpulan logis.

Salah satu model pembelajaran yang dapat digunakan untuk mengatasi rendahnya kemampuan penalaran matematis adalah pembelajaran dengan menggunakan model Reciprocal Teaching. Penggunaan model Reciprocal Teaching dapat meningkatkan kemampuan penalaran (Ardiansyah, 2015) dan mendorong siswa untuk bertanya (Sujati, 2005). Berdasarkan Nurhasanah (2009) reciprocal teaching menekankan adanya kegiatan bertanya (questioning), memprediksi (predicting), menjelaskan (clarifying) dan merangkum (summarizing). Menurut Shoimin (2014) Reciprocal Teaching adalah model pembelajaran dimana siswa berperan sebagai guru sedangkan guru sendiri lebih berperan sebagai fasilitator dan pembimbing.

\section{METODE PENELITIAN}

Penelitian ini merupakan penelitian tindakan kelas. Pada penelitian ini terdiri dari dua siklus. Di setiap siklus terdapat beberapa tahapan yaitu perencanaan, pelaksanaan, dan refleksi. Pada tahap perencanaan, peneliti menyusun seluruh instrumen yang dibutuhkan. Setelah semua instrumen siap digunakan, peneliti melaksanaan kegiatan penelitian. Kemudian dilakukan refleksi terhadap penelitian yang telah dilaksanakan. Instrumen penelitian terdiri dari RPP, lembar kerja siswa, kartu peran, lembar tes evaluasi, dan lembar observasi.

Analisis data diawali dengan menelaah seluruh data yang tersedia. Setelah ditelaah, dilakukan kegiatan reduksi data, menyajikan data, dan menarik kesimpulan. Pada reduksi data, peneliti memfokuskan data yang berkaitan dengan penalaran matematis. Reduksi data dilakukan di akhir siklus. Pada penyajian data, peneliti menyajikan data yang telah diperoleh dari reduksi data. Setelah data disajikan, dilakukan proses penarikan kesimpulan. Indikator keberhasilan penelitian adalah jika rata-rata persentase untuk kemampuan penalaran matematis minimal mencapai $70 \%$.

\section{HASIL DAN PEMBAHASAN}

Data-data yang diperoleh pada siklus I dalam penelitian ini dianalisis dengan menggunakan statistik sederhana yaitu dengan persentase keterlakasanaan pembelajaran dengan menggunakan strategi Resiprocal 


\section{Elisa Dewi Puspitasari}

Penerapan Reciprocal Teaching dengan Kartu Peran untuk Meningkatkan Kemampuan Penalaran Matematis Materi Trigonometri

Teaching dan penentuan skor tingkat kemampuan penalaran matematis dengan menggunakan rata-rata hasil tes evaluasi.

\section{Perencanaan Siklus I}

Pada tahap ini peneliti merancang tindakan yang terdiri dari lima langkah. (1) Menyiapkan Rencana Pelaksanaan Pembelajaran (RPP) materi trigonometri dengan mengunakan model pembelajaran Reciprocal Teaching dengan langkah-langkah kegiatan meliputi bertanya, memprediksi, menjelaskan dan merangkum. (2) Menyusun Lembar Kerja Siswa (LKPD). (3) Menyiapkan sumber dan media pembelajaran yang sesuai dengan RPP yang telah dirancang. (4) Menyiapkan kartu peran untuk membagi kelompok siswa secara acak sesuai dengan peran-peran yang ada dalam model pembelajaran Reciprocal Teaching. (5) Menyusun dan mempersiapkan soal tes evaluasi yang memuat indikator-indikator penalaran.

\section{Pelaksanaan Siklus I}

Pelaksanaan siklus I terdiri dari empat pertemuan.

\section{Pertemuan I}

Pertemuan pertama berjalan tidak sesuai dengan perencanaan. Terdapat beberapa tahapan dari langkah-langkah pembelajaran dengan menggunakan model Reciprocal Teaching ini yang belum terlaksana. Adapun tahapan yang belum terlaksana adalah tahap Predicting dan Summarizing. Berdasarkan hasil dari lembar observasi siswa dan guru pada pertemuan ini, diperoleh persentase keterlaksanaan pembelajaran dengan model Reciprocal Teaching yang masuk dalam kategori baik yaitu 75\% dan 69,4\% .

Pada pertemuan pertama tentang materi persamaan sinus, siswa terlihat lebih antusias dalam belajar daripada pertemuan sebelumnya yang tidak menggunakan model Reciprocal Teaching. Hal ini dikarenakan adanya pembagian peran pada model pembelajaran Reciprocal Teaching. Selama pembelajaran siswa terlihat bertanggungjawab terhadap peran masingmasing sehingga diskusi berjalan baik dan efektif. Dengan membaca materi dari buku siswa lebih mudah memahami materi yang diberikan. Pembagian peran untuk masing-masing siswa dilakukan secara acak dengan menggunakan lot. Hal ini membutuhkan waktu yang cukup lama, akan tetapi juga memperlihatkan adanya peningkatan antusiasme belajar.

Pembelajaran Reciprocal Teaching ini dimulai dengan tahapan Question Generating. Pada langkah ini masing-masing siswa menjalankan perannya dengan penuh tanggung jawab. Pada tahap Question Generating ini, muncul kendala dalam ketersediaan buku yang membuat masing-masing peran kesulitan menjalani tugas yang diberikan. Beberapa kelompok siswa menyiasati hal ini dengan memfoto halaman dari buku tersebut dengan menggunakan ponsel masing-masing. 


\section{Elisa Dewi Puspitasari}

Penerapan Reciprocal Teaching dengan Kartu Peran untuk Meningkatkan Kemampuan Penalaran Matematis Materi Trigonometri

Langkah selanjutnya masuk dalam tahap clarifying. Siswa melakukan diskusi kelas untuk mengkonfirmasi atau penyamaan persepsi siswa mengenai materi yang dipelajari. Pada saat diskusi kelas, dipilih salah satu kelompok untuk berperan sebagai "guru model" sedangkan peneliti berperan sebagai moderator diskusi. Pemilihan kelompok yang berperan sebagai "guru model' dilakukan oleh peneliti dengan pertimbangan efisiensi waktu. Kelompok siswa yang dipilih adalah kelompok siswa dianggap mampu menjelaskan dengan baik dan telah menyelesaikan lembar kerja kelompoknya. "Guru model" menjelaskan rangkuman yang diperoleh kelompoknya yang kemudian dilanjutkan dengan penyampaian pertanyaan oleh masing-masing penanya dari kelompok lainnya.

Pada pertemuan pertama siklus I ini, terdapat kesalahan pengaturan alokasi waktu yang menyebabkan beberapa tahapan belum terlaksana. Hal ini dikarekan kesalahpahaman alokasi waktu oleh peneliti. Karena pertemuan pertama ini dilaksanakan pada jam pertama dan kedua, peneliti tidak memperhatikan bahwa untuk jam pertama alokasi waktu terpotong 15 menit oleh kegiatan literasi siswa.

\section{Pertemuan II}

Pertemuan ini berjalan sesuai dengan perencanaan. Persentase keterlaksanaan pembelajaran Reciprocal Teaching pada pertemuan kedua ini sebesar $83 \%$ dan $80 \%$ yang masuk dalam kategori sangat baik. Langkahlangkah pada pertemuan ini tidak jauh berbeda dengan pertemuan pertama. Perbedaanya hanya pada penggunaan kartu peran sebagai alat untuk membagi kelompok siswa.

Seperti halnya pada pertemuan pertama, pembagian peran dan kelompok dilakukan bersamaan dengan pengecekan kehadiran. Hal ini dilakukan agar siswa lebih mudah menemukan dan bergabung bersama teman kelompoknya. Siswa mulai terbiasa dengan model yang digunakan dan adanya pembagian peran. Pada tahap question generating, alokasi waktu yang digunakan siswa lebih banyak daripada pada pertemuan sebelumnya yang berakibat pada alokasi waktu untuk tahap selanjutnya yaitu clarifying menjadi lebih sedikit. Salah satu penyebab penggunaan alokasi yang lebih banyak pada tahap question generating adalah pengerjaan LKS. Pada LKS tidak hanya terdapat tahap question generating, akan tetapi juga tahap predicting sehingga terdapat dua tahapan yang harus diselesaikan siswa secara bersamaan. Pada tahap predicting ini siswa ditugaskan untuk mencari permasalah tentang persamaan cosinus lain yang berbeda dengan masalah yang disajikan dalam lembar kerja. Setelah menyelesaikan tahap clarifying siswa, direncakan untuk menukarkan masalah yang diperolehnya dengan kelompok lain. Akan tetapi hal ini tidak terlaksana karena kurangnya waktu 


\section{Elisa Dewi Puspitasari}

Penerapan Reciprocal Teaching dengan Kartu Peran untuk Meningkatkan Kemampuan Penalaran Matematis Materi Trigonometri

dan beberapa kelompok siswa kesulitan menemukan atau membuat masalah yang berkaitan dengan persamaan cosinus.

Pada tahap clarifying, ditunjuk salah satu kelompok siswa yang berperan sebagai "guru model". Kendala pada tahap ini adalah siswa harus menuliskan kembali rangkuman yang diperolehnya di papan tulis, sehingga cukup menghabiskan waktu. Tahap selanjutnya adalah summarizing dimana masing-masing perangkum dalam kelompok membacakan kesimpulan yang diperoleh kelompoknya yang diakhiri dengan menyampaikan kesimpulan umum dari pembelajaran. Setelah tahap ini peneliti menutup pembelajaran.

\section{Pertemuan III}

Pada pertemuan ketiga dari siklus I ini pembelajaran berlangsung efektif. Siswa sudah terbiasa dengan model pembelajaran Reciprocal Teaching dan memahami alur pembelajaran. Pada kegiatan awal pembelajaran, peneliti membagi kelompok siswa menggunakan kartu peran berwarna yang dilanjutkan dengan menginformasikan tujuan dan memantapkan materi prasyarat. Beberapa siswa ditemukan melakukan kecurangan, dalam pengambilan kartu peran berwarna. Beberapa siswa lebih memilih peran perangkum dan menghindari peran penjelas. Hal tersebut dikarekan peran perangkum lebih mudah dilaksanakan, sedangkan peran penjelas memiliki tangggung jawab peran yang lebih besar.

Seperti halnya pertemuan-pertemuan sebelumnya, pada tahap question generating siswa diarahkan untuk membaca dan membuat pertanyaan dari materi yang diberikan. Sama halnya dengan pertemuan kedua, waktu yang digunakan siswa pada tahap ini lebih banyak karena adanya penggabungan dengan tahap predicting. Pada tahap ini beberapa siswa dapat menjalankan perannya dengan baik, sehingga dapat menyelesaikan tugas perannya lebih cepat dibandingkan dengan siswa lain . Hal ini mengakibatkan siswa yang lebih cepat menyelesaiakan tugasnya menganggur. Siswa yang menganggur cenderung tidak kondusif, sehingga peneliti menegaskan untuk membantu teman sekelompoknya yang belum menyelesaikan tugas perannya.

Pada pertemuan ini siswa juga sudah menyiapkan pertanyaanpertanyaan untuk tahap clarifiying. Pada pertemuan ini mulai muncul salah satu indikator penalaran matematis yang terakhir yaitu siswa dapat mengenali pola-pola atau melakukan generalisasi atas materi yang dipelajari. Pada tahap ini kelompok yang berperan sebagai "guru model" adalah kelompok hijau muda. Tahapan selanjutnya adalah summarizing, dimana setiap kelompok membacakan kesimpulan yang diperoleh selama pembelajaran dan diakhiri dengan kesimpulan secara umum dan peneliti menutup pembelajara.

\section{Tes Evaluasi}




\section{Elisa Dewi Puspitasari}

Penerapan Reciprocal Teaching dengan Kartu Peran untuk Meningkatkan Kemampuan Penalaran Matematis Materi Trigonometri

Hasil tes menunjukkan bahwa rata-rata kelas 60 dari 36 siswa yang mengikuti tes evaluasi. Berdasarkan hasil analisis hasil tes evaluasi diperoleh persentase siswa yang mampu melakukan penalaran. Dari hasil ini juga diperoleh rata-rata kemampuan penalaran siswa untuk semua indikator sebesar 60\%. Ditinjau dari hasil ini terdapat beberapa indikator yang berada pada kategori rendah yaitu dibawah $60 \%$ yakni indikator keempat tentang memeriksa keshahihan solusi yang diperoleh dan indikator kelima yaitu menentukan pola atau sifat-sifat dari suatu gejala matematis untuk membuat suatu generalisasi, hal ini karena siswa tidak terbiasa mengecek kembali apakah solusi dari permasalahan matematis yang mereka selesaiakan sudah benar atau tidak. Selain itu siswa jarang menghubungkan materi pelajaran persamaan trigonometri sederhana dengan meteri sebelumnya yang kadang harus digunakan untuk menyelesaikan permaslahan matematis yang diberikan, seperti mislnya menggunakan rumus perkalian sinus dan cosinus untuk menyederhanakan persamaan yang diberikan.

\section{Refleksi Siklus I}

Peneliti meninjau kembali pelaksanaan penelitian dan melakukan perbaikan-perbaikan sebagai solusi atas kendala-kendala yang ditemukan seperti disajikan dalam tabel 1 . Keterlaksanaan pembelajaran ini ditinjau berdasarkan lembar observasi.

Tabel 1 Keterlaksanaan Pembelajaran pada Siklus ke I

\begin{tabular}{|c|c|c|c|c|}
\hline \multirow{2}{*}{$\begin{array}{c}\text { Pert. } \\
\text { Ke- }\end{array}$} & \multicolumn{2}{|c|}{$\begin{array}{c}\text { Persentase } \\
\text { Keterlaksanaan }\end{array}$} & \multirow[t]{2}{*}{ Kendala } & \multirow[t]{2}{*}{ Solusi } \\
\hline & Guru & Siswa & & \\
\hline 1 & $75 \%$ & $69,4 \%$ & $\begin{array}{l}\text { 1. Kekurangan waktu } \\
\text { pada tahap } \\
\text { Quetsion } \\
\text { generating } \\
\text { 2. Ketersedian buku } \\
\text { paket } \\
\text { 3. Pembentukan } \\
\text { kelompok dengan } \\
\text { lot membuat siswa } \\
\text { kesulitan } \\
\text { menemukan teman } \\
\text { satu kelompoknya }\end{array}$ & $\begin{array}{l}\text { 1. Menambahkan } \\
\text { waktu untuk tahap } \\
\text { ini menjadi } 15 \text { menit } \\
\text { 2. Guru membuat } \\
\text { modul mandiri untuk } \\
\text { siswa } \\
\text { 3. Guru membuat kartu } \\
\text { peran berwarna } \\
\text { sehingga mudah } \\
\text { menemukan anggota } \\
\text { kelompok }\end{array}$ \\
\hline 2 & $83 \%$ & $80 \%$ & $\begin{array}{l}\text { 4. Kekurangan waktu } \\
\text { untuk presentasi } \\
\text { 5. Kelas kurang } \\
\text { kondusif sehingga } \\
\text { menjadi tidak }\end{array}$ & $\begin{array}{l}\text { 4. Diberikan batasan } \\
\text { waktu untuk } \\
\text { memikirkan jawaban } \\
\text { dari pertanyaan dan } \\
\text { tidak apa-apa apabila }\end{array}$ \\
\hline
\end{tabular}




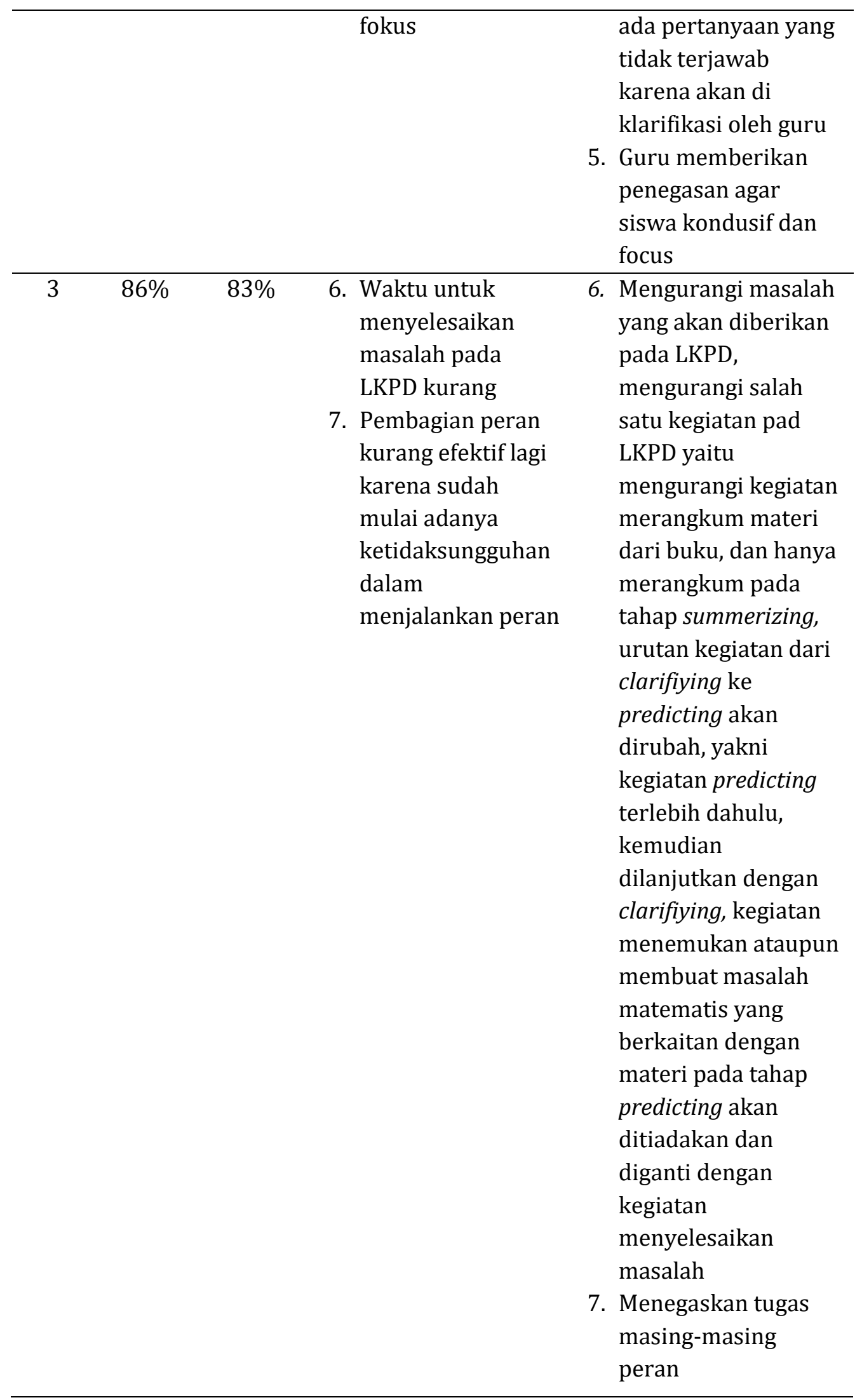


Elisa Dewi Puspitasari

Penerapan Reciprocal Teaching dengan Kartu Peran untuk Meningkatkan Kemampuan

Penalaran Matematis Materi Trigonometri

Selanjutnya dipaparkan sasil penelitian dan pelaksanaan penelitian pada siklus II.

\section{Perencanaan Siklus II}

Perancangan tindakan pada siklus II didasarkan hasil dari refleksi pada siklus I.

\section{Pelaksanaan Siklus II}

Pelaksanakan penelitian yang terbagi menjadi 3 kali pertemuan.

\section{Pertemuan I}

Pada pertemuan pertama, peneliti melakukan beberapa perubahan untuk mengatasi kendala-kendala pada siklus I. Salah satu perubahan tersebut terdapat pada kegiatan Predicting, dimana pada siklus I dilakukan dengan menugaskan siswa mencari permasalahan baru yang berbeda dengan permasalahan yang diberikan pada LKPD, yang kemudian ditukarkan dengan kelompok lain. Sedangkan pada siklus kedua ini, tahap predicting dilakukan bersamaan dengan tahap question generating dimana siswa menyelesaikan masalah yang diberikan sebagai salah satu tahap predicting. Selain itu peda siklus ke II ini juga, permasalah yang berkaitan dengan materi yang diberikan pada LKPD dikurangi, sebagai salah satu solusi untuk mengefisiensikan alokasi waktu pembelajaran.

Langkah-langkah pembelajaran model Reciprocal Teaching terlaksana sesuai dengan waktu yang dialokasikan. Berdasarkan lembar observasi diperoleh persentase keterlaksanaan pembelajaran dengan menggunakan model Reciprocal Teaching sebesar 92\% yang mana masuk dalam kategori sangat baik. Peneliti melakukan pengecekan kehadiran yang dibarengi dengan pembagian peran dan kelompok menggunakan kartu peran. Terdapat beberapa siswa yang mengeluh dikarenakan selalu mendapat peran yang sama. Menanggapi permasalah tersebut, peneliti kembali mengacak kartu peran, dan menegaskan kepada beebrapa siswa yang sebelumnya melakukan kecurangan dalam memilih kartu untuk mengabil kartu sesuai acakan yang sudah dipersiapkan.

Selanjutnya, peneliti menginformasikan tujuan, tugas peran, dan materi, serta melakukan pemantapan materi prasyarat yang dibutuhkan untuk mempelajari materi tersebut. salah satu materi yang menjadi prasyarat untuk persamaan trigonometri bentuk khusus adalah penyelesaian persamamaan trigonometri bentuk sederhana. Beberapa siswa diketahui lupa dengan materi yang baru saja dipelajari tersebut yang disebabkan karena rentang antar pertemuan sebelumnya lumayan jauh yang banyak berbenturan dengan kegiatan sekolah dan hari libur.

Langkah selanjutnya memasuki tahap question generating. Perbedaan dengan siklus sebelumnya terletak pada sumber belajar yang digunakan. Pada siklus ini digunakan modul yang dibuat peneliti sebagai pengganti buku 


\section{Elisa Dewi Puspitasari}

Penerapan Reciprocal Teaching dengan Kartu Peran untuk Meningkatkan Kemampuan Penalaran Matematis Materi Trigonometri

matematika pada siklus sebelumnya. Modul dibuat dalam bentuk online, sehingga masing-masing siswa dapat mengakses modul tersebut melalui ponselnya masing-masing. Dari modul yang telah dibagikan tersebut, siswa diarahkan untuk membuat pertanyaan dan sekaligus menggunakan modul tersebut untuk memprediksi pemecahan masalah yang disajikan pada LKPD.

Pada pertemuan pertama siklus ke II ini peneliti memberitahukan alokasi waktu penyelesaian LKPD, dan menegaskan bahwa setiap kelompok harus siap berperan sebagai "guru model". Pada tahap clarifying peneliti menunjuk salah satu kelompok secara acak untuk menjadi guru model. Penjelasan dari kelompok "guru model" menjawab semua pertanyaan dari masing-masing kelompok. Tahap selanjutnya adalah tahap summarizing dimana beberapa kelompok membacakan kesimpulan kelompoknya dan diakhiri denngan kesimpulan secara umum serta peneliti menutup pembelajaran.

\section{Pertemuan II}

Materi yang diajarkan adalah persamaan trigonometri yang dapat diselesaikan dengan menggunakan konsep persamaan kuadrat yang merupakan materi perluasan dari materi persamaan trigonometri. Berdasarkan lembar observasi guru dan siswa diperoleh persentase pelaksanaan pembelajan dengan menggunakan model Reciprocal Teaching sebesar $97 \%$ yaitu artinya sangat baik.

Pada saat clarifying muncul pertanyaan-pertanyaan antara lain: "Apa konsep persamaan kuadrat pada persamaan trigonometri hanya berlaku untuk bentuk khusus $a \sin ^{2} x+b \sin x+c=0$ ?". "Bagaimana cara mengubah persamaan trigonometri menjadi bentuk persamaan kuadrat?". "Persamaan trigonometri yang seperti apa yang dapat diselesaikan dengan menggunakan konsep persamaan kuadrat?". "Mengapa penyelesaian persamaan trigonometrinya harus difaktorkan terlebih dahulu ?". Pertemuan ini juga tidak luput dari kendala yaitu munculnya ketidaksungguhan siswa untuk dalam menjalankan perannya dikarenakan adanya rasa bosan dengan model yang digunakan. Untuk mengatasi kendala tersebut guru memotivasi dan memberikan penguatan di kelas.

\section{Tes Evaluasi}

Hasil tes menunjukkan rata-rata kelas sebesar 73 yang menunjukkan peningkatan dari siklus sebelumnya. Indikator pertama yaitu membuat dugaan-dugaan yang terkait dengan persoalan matematis dari $86 \%$ meningkat menjadi $87 \%$. Terdapat peningkatan sebesar $1 \%$. Indikator kedua yaitu melakukan manipulasi matematika terhadap persoalan matematis yang telah dipelajari sebelumnya dari $85 \%$ turun menjadi $77 \%$. Hal ini dikarenakan tingkat ketelitian siswa menurun, kebanyakan siswa bisa akan tetapi salah dalam perhitunganya, seperti misalnya kurangnya tanda negatif 


\section{Elisa Dewi Puspitasari}

Penerapan Reciprocal Teaching dengan Kartu Peran untuk Meningkatkan Kemampuan Penalaran Matematis Materi Trigonometri

dan sebagainya. Indikator ketiga yaitu menarik kesimpulan yang merupakan solusi dari suatu permasalahan matematis dari 73\% turun menjadi 67\%. Hal ini akibat dari turunnya persentasi pada indikator kedua yang juga berpengaruh terhadap indikator ketiga ini. Dikarenakan manipulasi yang dilakukan kurang tepat mengakibatkan kesimpulan yang di peroleh pun kurang tepat. Indikator keempat yaitu memeriksa keshahihan solusi yang diperoleh dari 4,9\% meningkat menjadi 65\%. Peningkatan ini terjadi karena diberikan penguatan untuk memeriksakan kembali jawaban yang diperoleh dan mencocokkan dengan syarat yang diberikan pada permasalahan matematis tersebut. Indikator kelima yaitu menentukan pola atau sifat dari suatu gejala matematis untuk membuat suatu generalisasi dari 49\% meningkat menjadi $71 \%$.

Dari penjabaran diatas diperoleh peningkatan rata-rata persentase kemampuan penalaran dan peningkatan rata-rata kelas menjadi 73. Sehingga indikator keberhasilan telah tercapai dan siklus dari penelitian ini dapat dihentikan.

\section{Refleksi Siklus II}

Refleksi pada siklus II ditujukan untuk mengatasi berbagai kendala yang dihadapi.

Tabel 2 Keterlaksanaan Pembelajaran pada Siklus ke II

\begin{tabular}{|c|c|c|c|c|}
\hline \multirow{2}{*}{$\begin{array}{l}\text { Pert. } \\
\text { Ke- }\end{array}$} & \multicolumn{2}{|c|}{$\begin{array}{c}\text { Persentase } \\
\text { Keterlaksanaan }\end{array}$} & \multirow[t]{2}{*}{ Kendala } & \multirow[t]{2}{*}{ Solusi } \\
\hline & Guru & Siswa & & \\
\hline 1 & $92 \%$ & $92 \%$ & $\begin{array}{l}\text { 1. Perbedaan waktu } \\
\text { dalam } \\
\text { menyelesaikan } \\
\text { tugas masing- } \\
\text { masing peran } \\
\text { menyebakan } \\
\text { peserta didk tidak } \\
\text { fokus }\end{array}$ & $\begin{array}{l}\text { 1. Diberikan tugas } \\
\text { tambahan kepada } \\
\text { siswa yang dapat } \\
\text { mengerjakan } \\
\text { tugasnya lebih cepat } \\
\text { yaitu dengan } \\
\text { membantu teman } \\
\text { kelompoknya yang } \\
\text { belum } \\
\text { menyelesaiakn } \\
\text { tugas yang } \\
\text { diberikan }\end{array}$ \\
\hline 2 & $97 \%$ & $97 \%$ & $\begin{array}{l}\text { 2. Adanya } \\
\text { ketidaksungguhan } \\
\text { siswa dalam } \\
\text { menjalankan } \\
\text { perannya } \\
\text { dikarenakan mulai }\end{array}$ & $\begin{array}{l}\text { 2. Diberikan penguatan } \\
\text { dan motivasi agar } \\
\text { menyelesaikan tugas } \\
\text { dengan penuh } \\
\text { semangat }\end{array}$ \\
\hline
\end{tabular}


Berdasarkan hasil analisis diperoleh rata-rata persentasi untuk kemampuan penalaran matematis meningkat dari $60 \%$ menjadi $73 \%$. Dengan demikian, pembelajaran Reciprocal Teaching dengan kartu peran dapat meningkatkan kemampuan penalaran matematis siswa. Hal ini sejalan dengan pernyataan Ardiansyah (2015) bahwa pembelajaran matematika dengan Reciprocal Teaching dapat meningkatkan penalaran matematis siswa. Langkah kegiatan dalam Reciprocal Teaching berhubungan dengan indikator penalaran. Kegiatan questioning memiliki hubungan dengan indikator mengajukan pertanyaan dan memberikan alasan terhadap kebenaran solusi, kegiatan clarifying memiliki hubungan dengan indikator menganalisis pernyataan dan memberikan alasan terhadap kebenaran solusi, kegiatan summarizing memiliki hubungan dengan indikator menganalisis pernyataan dan membuat kesimpulan logis, dan kegiatan predicting memiliki hubungan dengan indikator membuat kesimpulan logis (Latifa, 2017).

Kemampuan penalaran sangat dibutuhkan dalam pembelajaran matematika. Materi matematika dan penalaran matematis sangat terkait dan tidak dapat dipisahkan (Gustiati, 2016). Hal yang sama juga dinyatakan (Konita, Asikin \& Asih, 2019) bahwa menyelesaikan masalah matematis memerlukan penalaran dan kemampuan penalaran dapat diasah dari belajar matematika. Kemampuan penalaran juga merupakan pondasi dalam pembelajaran matematika (Nita \& Surya, 2017) dan berperan dalam pemahaman konsep dan pemecahan masalah dalam pembelajaran matematika ((Wulandari, 2011). Selain itu, kemampuan penalaran matematis dapat membantu siswa dalam menyimpulkan dan membuktikan suatu pernyataan, memuat gagasan baru, sampai pada menyelesaikan masalahmasalah dalam matematika (Sumartini, 2015).

\section{KESIMPULAN DAN SARAN}

Penerapan model Reciprocal Teaching mampu meningkatkan kemampuan penalaran matematis siswa kelas XI IPA 2 SMA Negeri 8 Malang pada materi Persamaan Trigonometri dengan meningkatnya rata-rata kelas menjadi 60 pada siklus I dan menjadi 73 pada siklus ke II. Selain itu rata-rata persentase peningkatan penalaran matematis siswa juga meningkat dari $60 \%$ menjadi 73\%. Penelitian ini dapat digunakan sebagai salah satu rujuan untuk penelitian selanjutnya yang berfokus pada peningkatan kemampuan matematis lainnya dengan menerapkan pembelajaran reciprocal teaching. 


\section{Elisa Dewi Puspitasari}

Penerapan Reciprocal Teaching dengan Kartu Peran untuk Meningkatkan Kemampuan

Penalaran Matematis Materi Trigonometri

\section{DAFTAR RUJUKAN}

Ardiansyah, H. (2015). Penerapan Reciprocal teaching untuk Meningkatkan Penalaran Matematis Siswa pda Materi Relasi dan Fungsi Kelas X MIPA SMA Laboratorium UM. Universitas Negeri Malang.

Arifendi, R. F., \& Setiawan, R. (2019). Upaya Peningkatan Penalaran Matematis Mahasiswa Universitas Tribhuwana Tunggadewi Melalui Pendekatan Contextual Teaching and Learning (CTL). Prismatika, 1(2), 55-59.

Gustiati, M. (2016). Profil Kemampuan Penalaran Matematis dalam Pemecahan Masalah Ditinjau dari Kecerdasan Emosional dan Gaya Belajar Siswa. Universitas Negeri Makasar.

Hamalik, O. (2003). Proses Belajar Mengajar. Jakarta: Bumi Aksara.

Konita, M., Asikin, M., \& Asih, T. S. N. (2019). Kemampuan Penalaran Matematis dalam Model Pembelajaran Connecting, Organizing, Reflecting, Extending (CORE). Prisma (Prosiding Seminar Nasional Matematika) 2, 611-615.

Latifa, A. N. (2017). Reasoning and Proof dalam Model Pembelajaran Reciprocal teaching Materi Trigonometri Siswa SMA. Indonesian Digital Journal of Mathematics and Education, 4(6), 389-399.

Nita, N., \& Surya, E. (2017). Membangun Kemampuan Penalaran Matematis (Reasoning Mathematics Ability) dalam Pembelajaran Matematika. Retrieved March 20, 2020, from https://www.researchgate.net/publication/321825158_MEMBANGUN_K EMAMPUAN_PENALARAN_MATEMATIS_REASONING_MATHEMATICS_AB ILITY

Nurhasanah, S. (2009). Pengaruh Pendekatan Reciprocal teaching terhadap Kemampuan Berfikir Kritis Siswa Dalam Belajar Matematika (Studi Eksperimen SMP Al-Hasra Depok). Retrieved from http://repository.uinjkt.ac.id/dspace/bitstream/123456789/3031/1/SU FINA NURHASANAH-FITK.pdf

Ramdani, Y. (2011). Enhancement Of Mathematical Reasoning Ability At Senior High School By The Application Of Learning With Open Ended Approach. In Seminar and the Fourth National Conference on Mathematics Education. Universitas Negeri Yogyakarta.

Ramdani, Y. (2012). Pengembangan Instrumen dan Bahan Ajar untuk Meningkatkan Kemampuan Komunikasi, Penalaran, dan Koneksi Matematis dalam Konsep Integral. Jurnal Penelitian Pendidikan, 13(1), 4452.

Ridwan, M. (2017). Profil Kemampuan Penalaran Matematis Siswa Ditinjau dari Gaya Belajar. Kalamatika, 2(2), 193-206.

Shoimin, A. (2014). 68 Model dalam Pembelajaran Inovatif dalam Kurikulum 2013. Yogyakarta: Ar-Ruzz Media.

Sujati. (2005). Mengenal Reciprocal teaching Sebagai salah Satu Model Pembelajaran. Majalah Ilmiah Kependidikan: Pelangi Pendidikan. Retrieved from https://eprints.uny.ac.id/4459/1/Majalah_Ilmiah_Kependidikan_\%28PE 


\section{Elisa Dewi Puspitasari}

Penerapan Reciprocal Teaching dengan Kartu Peran untuk Meningkatkan Kemampuan

Penalaran Matematis Materi Trigonometri

\section{LANGI_PENDIDIKAN\%29_-}

_Mengenal_Reciprocal_Teaching_sebagai_Salah_Satu_Model_Pembelajaran .pdf

Sumartini. (2015). Peningkatan Kemampuan Penalaran Matematis Siswa Melalui Pembelajaran Berbasis Masalah. Jurnal Pendidikan Matematika, 5(1), 1-10.

Wulandari, E. (2011). Meningkatkan Kemampuan Penalaran Matematis Siswa melalui Pendekatan Problem Posing di Kelas VIII A SMP Negeri 2 Yogyakarta. Universitas Negeri Yogyakarta. 